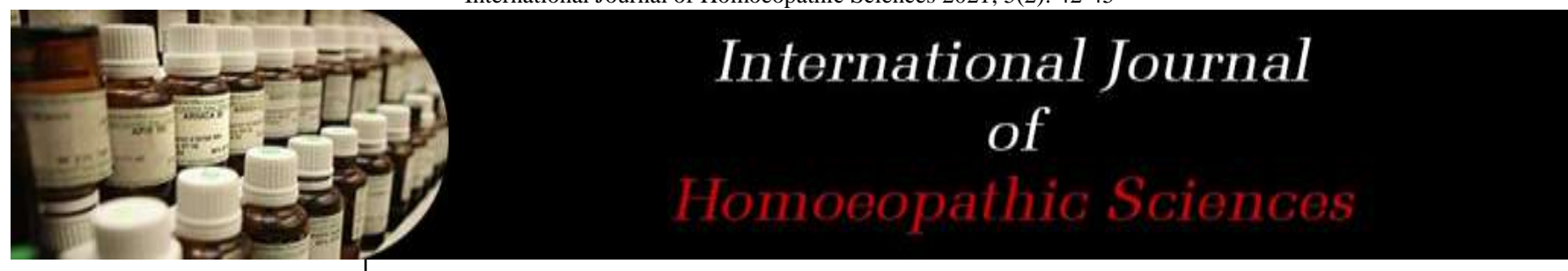

E-ISSN: 2616-4493 P-ISSN: 2616-4485 www.homoeopathicjournal.com IJHS 2021; 5(2): 42-45 Received: 23-01-2021 Accepted: 28-02-2021

Dr. Subhash Chand Yadav Professor, PG Guide, Department of Repertory, Swasthya Kalyan

Homoeopathic Medical College and Research Centre, Sitapura, Jaipur, Rajasthan, India

Dr. Anshuman Kankoriya MD (PGR), Department of Repertory, Swasthya Kalyan Homoeopathic Medical College and Research Centre, Sitapura, Jaipur, Rajasthan, India
Corresponding Author:

Dr. Subhash Chand Yadav Professor, PG Guide, Department of Repertory, Swasthya Kalyan Homoeopathic Medical College and Research Centre, Sitapura, Jaipur, Rajasthan, India

\section{Molluscum contagiosum treated with homoeopathic medicine: A case study}

\author{
Dr. Subhash Chand Yadav and Dr. Anshuman Kankoriya
}

DOI: https://doi.org/10.33545/26164485.2021.v5.i2a.362

\section{Abstract}

Molluscum contagiosum (MC) is a self - limited infectious dermatosis, it is frequently develop in pediatric age group, adults which are sexually active and individuals who are immune-compromised. It is also called water warts. Lesion of molluscum contagiosum appears dome shaped, round with pink \& purplish color. A 32 year female patient reported with complaints of dome shaped eruption with pinkish color below right eyebrow \& back of the left hand. Case taking was done followed by repertorization using Synthesis 9.0 repertory Radar 10.0 and Sulphur has been given as an individualized medicine.

Keywords: Homoeopathy, Molluscum contagiosum, RADAR, sulphur

\section{Introduction}

Molluscum contagiosum (MC) is a self - limited infectious dermatosis, it is frequently develop in pediatric age group, adults which are sexually active and individuals who are immunocompromised ${ }^{[1]}$

It is also called water warts. Lesion of molluscum contagiosum appears dome shaped umbilicated, round with pink \& purplish color ${ }^{[2]}$.

$\mathrm{MC}$ is caused due to molluscum contagiosum virus (MCV), this virus is double strand DNA virus which is belong to poxviridae family, the host of this virus is only humans ${ }^{[1]}$.

$\mathrm{MCV}$ transmitted by direct contact person who is suffering from MCV, this contact can be sexual or non-sexual. MCV also transmitted by contaminated fomites like bath sponges or towels ${ }^{[1]}$

\section{Case study}

Mrs. XY, 32 year, female, normal built, with fair complexion, Hindu, married, Vegetarian, house wife, attended the out-patient department of the Swasthya kalyan homoeopathic medical college and research centre, sitapura, Jaipur (Rajasthan) present herself with the known case of molluscum contagiosum on 15/06/2020, on further enquiry she told that complaint had started gradually since 4 months. Complaining of dome shaped eruption below right eyebrow \& back of the left hand. She took alternative medicines orally and as an external application applies many ointments on eruptions but no relief.

Father $56 \mathrm{yr}$ of age has a history of HTN since $20 \mathrm{yrs}$, mother is healthy $54 \mathrm{yr}$ of age.

The mental general reflected anger violent, give answer abruptly, anxiety about health, dictatorial and has a fear of high places.

Regarding her past history the patient further reported that she had suffered from repeated attacks of cold and coryza which was cured of after taking alternative treatment.

She had strong desire for taking sweets.

Stool hard, constipated with constant desire.

Perspiration especially on axilla.

Tongue - clean moist.

Thermal - hot.

\subsection{Analysis of case}

\subsubsection{Mental general}

- She is very irritable and aggressive in nature.

- Always answers everything abruptly.

- She never listens to anybody always do what she likes and everyone has to follow that 
otherwise she gets angry.

- She is very health conscious, take great care of her even in small complaints.

- She has fear from height.

\subsubsection{Physical general}

- Stool-hard, constipated with constant desire.

- Tongue-Clean \& moist.

- Desire - Sweets.

- Perspiration- Especially on axilla.

- Thermal - Hot.

\subsubsection{Particulars}

- Molluscum contagiosum below right eyebrow \& back of the left hand.

\subsection{Evaluation}

- She is very irritable and aggressive in nature.

- Always answers everything abruptly.

- She never listens to anybody always do what she likes and everyone has to follow that otherwise she gets angry.

- She is very health conscious, take great care of her even in small complaints.

- She has fear from height.

- Molluscum contagiosum below right eyebrow \& back of the left hand.

- Stool-hard, constipated with constant desire.
- Tongue-Clean \& moist.

- Desire - Sweets.

- Perspiration - Especially on axilla.

- Thermal - Hot.

2.3 Totality of symptoms

- Answer abruptly.

- Anger violent.

- Anxiety about her health.

- Dictatorial.

- Fear of high places.

- Molluscum.

- Stool constipated with constant desire.

- Desire for sweets.

\subsection{Rubric}

\begin{tabular}{|c|c|c|}
\hline S. No. & Chapter & Rubric \\
\hline 1. & Mind & Answering - abruptly \\
\hline 2. & Mind & Anger - violent \\
\hline 3. & Mind & Anxiety- health; about - own health; one's \\
\hline 4. & Mind & Dictatorial \\
\hline 5. & Mind & Fear - high places, of \\
\hline 6. & Skin & Eruptions - molluscum \\
\hline 7. & Rectum & Constipation - constant desire \\
\hline 8. & Generals & Food and drinks - sweets - desire \\
\hline
\end{tabular}

\subsection{Repertorial sheet ${ }^{[7]}$}

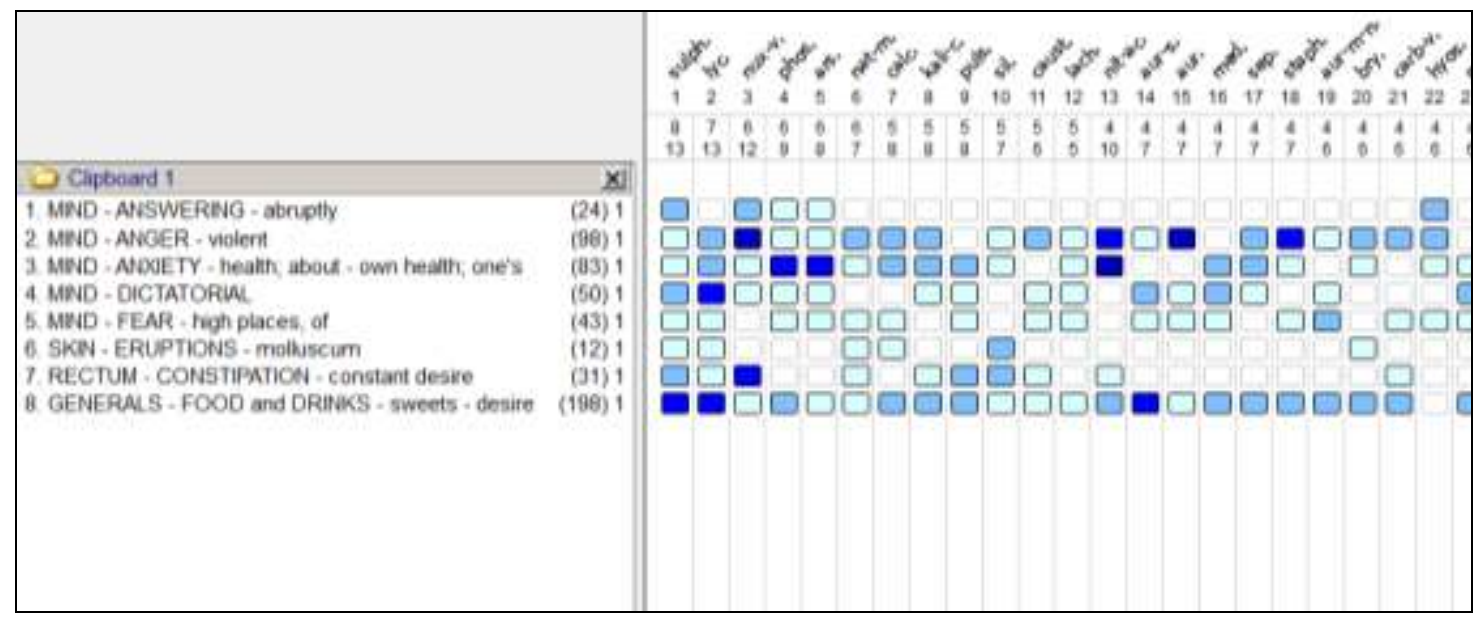

Fig 1: Showing repertorization of case from synthesis 9.0 repertory using Radar (version 10.0)

\subsection{Analysis of reportorial result}

\begin{tabular}{|c|c|c|}
\hline S. No. & Medicine & Mark obtain \\
\hline 1. & Sulphur & $13 / 8$ \\
\hline 2. & Lycopodium clavatum & $13 / 7$ \\
\hline 3. & Nux vomica & $12 / 6$ \\
\hline 4. & Phosphorus & $9 / 6$ \\
\hline 5. & Arsenicum album & $8 / 6$ \\
\hline
\end{tabular}

\subsection{Selection of medicine}

Sulphur seems to suit the case not only because it get highest marks during repertorization but also cover most of the symptoms of the case. Patient has marked mental symptoms like answer abruptly, anger violent, anxiety about her health, dictatorial \& fear of high places. Desire for sweets and patient thermally hot.

\subsection{Prescription}

\begin{tabular}{|c|c|}
\hline Date & Prescription \\
\hline \multirow{2}{*}{$15 / 06 / 2020$} & Rx \\
& Sulphur 200 1 Dose Stat \\
& Rubrum 30 TDS 6 Hourly x 15 Days \\
\hline
\end{tabular}

\subsection{Follow-up sheet}

\begin{tabular}{|c|l|c|}
\hline Date & \multicolumn{1}{|c|}{ Symptoms } & Prescription \\
\hline \multirow{2}{*}{ 30/06/2020 } & Complaints of eruption stand still. & Rx \\
& Partial improvement in hard stool. & Rubrum 30 TDS 6 Hourly x 15 Days \\
\hline
\end{tabular}




\begin{tabular}{|c|c|c|}
\hline 13/07/2020 & $\begin{array}{l}\text { Improvement in eruption. } \\
\text { Stool regular slight hard with straining. }\end{array}$ & $\begin{array}{c}\text { Rx } \\
\text { Rubrum } 30 \text { TDS } 6 \text { Hourly x } 15 \text { Days }\end{array}$ \\
\hline 29/07/2020 & Complaint is stand still. & $\begin{array}{c}\text { Rx } \\
\text { Sulphur 200 } 1 \text { Dose Stat } \\
\text { Rubrum 30 TDS 6 Hourly x 15 Days }\end{array}$ \\
\hline $14 / 08 / 2020$ & $\begin{array}{l}\text { Stool regular, soft. } \\
\text { Improvement in eruption, no new eruption comes after medication. }\end{array}$ & $\begin{array}{c}\text { Rx } \\
\text { Rubrum 30 TDS } 6 \text { Hourly x } 15 \text { Days }\end{array}$ \\
\hline $1 / 09 / 2020$ & $\begin{array}{c}\text { Decrease in size of eruptions. } \\
\text { Stool regular soft, satisfactory. } \\
\end{array}$ & $\begin{array}{c}\text { Rx } \\
\text { Rubrum } 30 \text { TDS } 6 \text { Hourly x } 15 \text { Days }\end{array}$ \\
\hline $16 / 09 / 2020$ & Eruptions size is same, slight hardness in stool since 2 days. & $\begin{array}{c}\text { Rx } \\
\text { Sulphur 1M } 1 \text { Dose Stat } \\
\text { Rubrum 30 TDS 6 Hourly x 15 Days } \\
\end{array}$ \\
\hline $3 / 10 / 2020$ & $\begin{array}{l}\text { No complaint of hardness of stool. } \\
\text { Size of eruptions reduces. }\end{array}$ & $\begin{array}{c}\text { Rx } \\
\text { Rubrum } 30 \text { TDS } 6 \text { Hourly x } 15 \text { Days }\end{array}$ \\
\hline 19/10/2020 & $\begin{array}{l}\text { Reduce in size of corn. } \\
\text { Stool satisfactory, regular, soft in consistency. }\end{array}$ & $\begin{array}{c}\text { Rx } \\
\text { Rubrum 30 TDS } 6 \text { Hourly x } 30 \text { Days } \\
\end{array}$ \\
\hline $18 / 11 / 2020$ & No eruption below eyebrow and back of the left hand. & $\begin{array}{c}\text { Rx } \\
\text { Rubrum 30 TDS } 6 \text { Hourly x } 30 \text { Days }\end{array}$ \\
\hline $17 / 12 / 2020$ & $\begin{array}{l}\text { No complaint of eruptions. } \\
\text { Patient feel good. }\end{array}$ & $\begin{array}{c}\text { Rx } \\
\text { Rubrum 30 TDS } 6 \text { Hourly x } 30 \text { Days }\end{array}$ \\
\hline
\end{tabular}

\subsection{Picture}

\subsubsection{Before treatment}
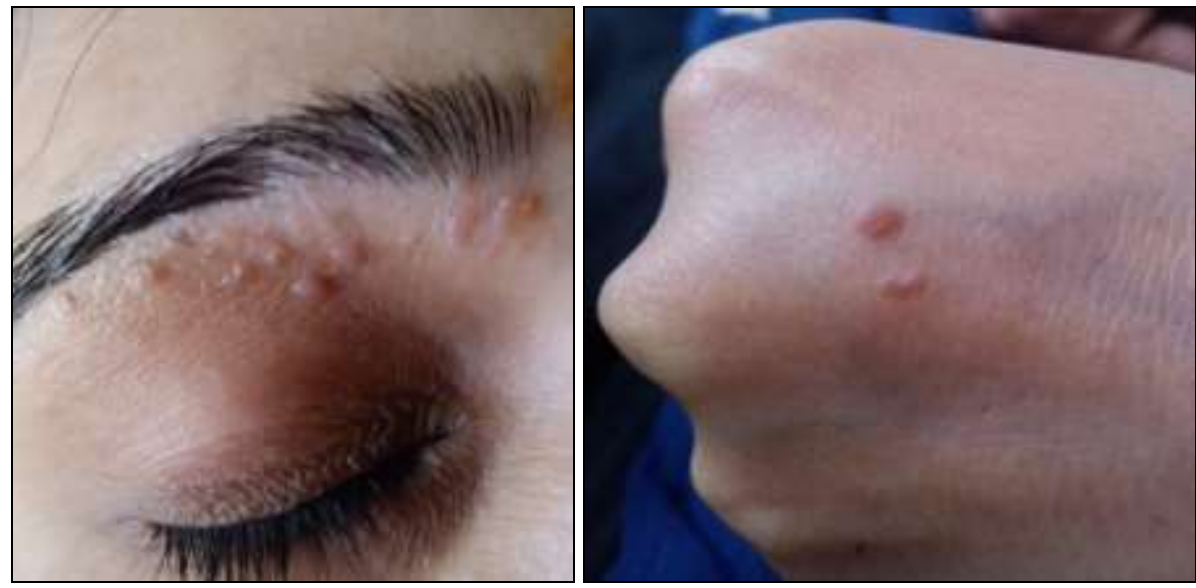

\subsubsection{After treatment}
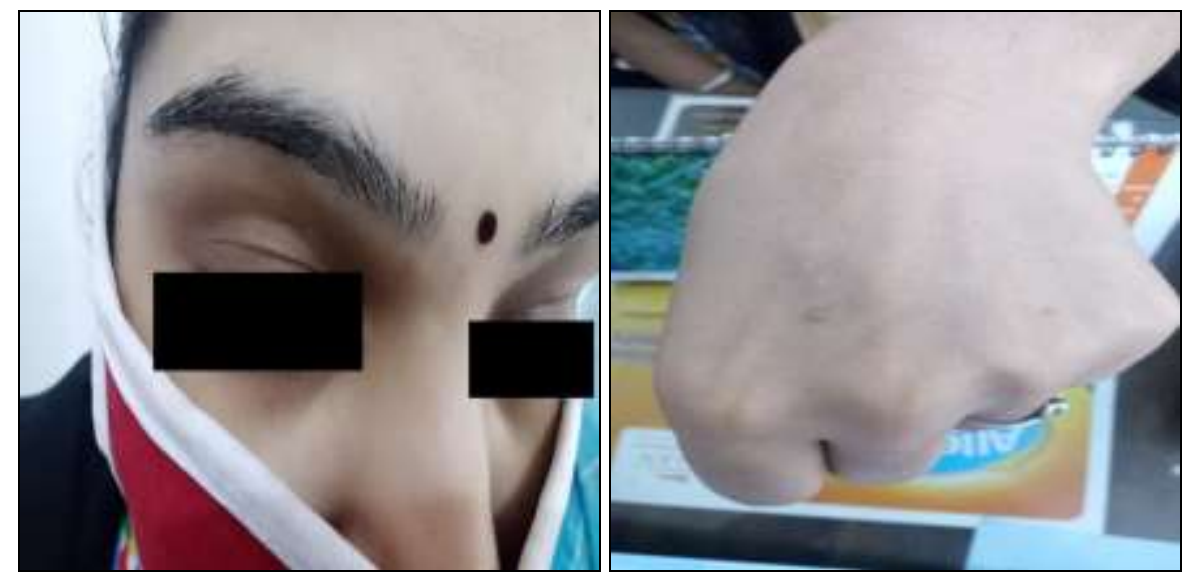

\section{Conclusion}

Homoeopathy have massive and beautiful work on the quality of life (Qol) of those who are suffering from Molluscum contagiosum, homoeopathy has proven its effectiveness in such type of cases and so this case further proves the therapeutic value and strong power of homoeopathic medicines in treatment of Molluscum contagiosum.

\section{References}

1. Meza-Romero R, Navarrete-Dechent C, Downey C. Molluscum contagiosum: An update and review of new perspectives in etiology, diagnosis, and treatment. Clin Cosmet Investig Dermatol 2019;12:373-381.

2. Badri T, Gandhi GR. Molluscum contagiosum. Stat Pearls 2020.

3. Dr. Samuel Hahnemann (B.K. Sarkar): Organon of Medicine, $5^{\text {th }} \& 6^{\text {th }}$ Edition, $8^{\text {th }}$ Indian Edition, Pub: M. 
Bhattacharya \& Co. (p) Ltd., Calcutta-1 1984.

4. Dr. Ramanlal Patel P. The Art of Case Taking and Practical Repertorisation in Homoeopathy, $5^{\text {th }}$ Edition, Pub.: Dr. J.R. Patel Hahnemann House, Kottayam (Kerala)-686 0011990.

5. Farrington EA. M.D: Comparative Materia Medica, Pub: B. Jain Publishers Pvt. Ltd., New Delhi-110 055 1986.

6. Clark JH. A Dictionary of Practical Materia Medica. Delhi. B. Jain. Publications 2003;1, 2, 3.

7. Computer Repertory: RADAR (Version 10.0), Schroyens F., Synthesis 9.0 (English). 